SCJR 14, no. 1 (2019): 1-4

\title{
Matthias Henze Mind the Gap: \\ How the Jewish Writings between the Old and New Testament Help Us Understand Jesus
}

(Minneapolis: Fortress Press, 2017), 248 pages

\author{
SIMON J. JOSEPH \\ simonjoseph@humnet.ucla.edu \\ University of California, Los Angeles, CA 90095
}

Jesus was Jewish. While this historical truism seems obvious to biblical scholars and historians, Jesus' Jewishness still represents something of a disconnect, or perhaps even a "gap," in the knowledge of the average Christian. For many, Jesus may have been nominally Jewish, but he is more commonly regarded as the honorary founder of Christianity. In Mind the Gap, a book about "the Jewish world of the New Testament" (p. 181), Matthias Henze attempts to correct this distorted perspective by focusing on the Intertestamental literature of Second Temple Judaism, that is, the "gap" between the Old and New Testaments. Borrowing the phrase from the London Underground's caution to "mind the gap" between the platform and oncoming trains, Henze develops this concept of a literary-theological "gap" in our understanding of the historical context of early Christianity by focusing on a number of specific themes and topics - particularly messianism, demons, exorcism, the Law, and resurrection-that are indispensable to understanding the ministry of Jesus in the New Testament.

The book is divided into two parts. Part I ("Mind the Gap! Reading between the Old and New Testament") has two chapters and contains Henze's brief review of the history of ancient Israel and the writings of the "Old Testament." Part II ("The Jewish Jesus") has five chapters focusing on the most significant themes of Intertestamental literature. In chapter 3 ("Jesus, the Messiah of Israel"), for example, Henze explores the origins of Jewish messianism in the Intertestamental period, highlighting Jesus' identification as "anointed / messiah," or "Christ(os)," within its Jewish literary-theological context. The New Testament writings were written to proclaim, if not to prove, that Jesus was the Messiah of Israel. They did 
so by appealing to the "Old Testament's" prophetic corpus as well as to more recent writings like the book of Daniel and the Enochic Book of Parables, both of which refer to a heavenly and / or human-like figure ultimately identified as the Son of Man. Henze also explores the significance of the discovery of the Dead Sea Scrolls, in particular, 4Q521 ("The Messianic Apocalypse") and 4Q246 ("The Son of God Text") from Qumran (pp. 68-85). 4Q521 refers to the "heavens and the earth" listening to "his [God's] messiah" and describes the eschatological blessings of the messianic age in a way reminiscent of Jesus' acts of healing during his ministry as seen in Luke. Henze suggests that it was "originally composed somewhere else and then brought to Qumran" and so may not "express the beliefs of the community" (p. 173). This may well be the case, as many texts found at Qumran were not written there, but one might also ask why a text preserved, collected, and copied by Qumran members would not "express the beliefs of the community."

In chapter 4 ("In a World of Demons and Unclean Spirits") (pp. 87-114), Henze carefully shows how belief in demons and unclean spirits arose not from the "Old Testament" period of ancient Israel but from the Intertestamental "gap" period when Jewish scribes were influenced by the Enochic writings. This illuminates how the New Testament writers could presuppose, if not take for granted, their audience's recognition of the reality of a densely populated demonic world.

In an important discussion focused on Jesus' relationship to the Mosaic Law in chapter 5, "Did Jesus Abolish the Law of Moses?" (pp. 115-46), Henze clarifies the terminology of "torah" as instruction, teaching, and / or law. He shows that the concept of torah was being developed and interpreted in Jewish literature of this time. He suggests that the Matthean Jesus affirms and "fulfills" the law even while his interpretation (or torah!) could challenge others' interpretations of torah.

In chapter 6 ("The Resurrection of the Dead and Life in the Company of Angels") (pp. 147-79), Henze reviews a number of texts, including Daniel 12:1-3, 2 Maccabees 7, Psalms of Solomon 17, 1 Enoch 51, and 4 Ezra 7, which discuss the increasingly common belief in eschatological resurrection. He traces the development of this belief beginning in the relatively early texts of Daniel and 2 Maccabees, where resurrection is "a promise that is made to a specific group and in response to a concrete historical crisis" but is not made to "all of Israel, let alone [to] humanity in general" (p. 168). He notes a later shift to a "less restricted" promise, so that by the first century CE it becomes "a fixed part of Jewish end time expectations." Each of these chapters represent excellent summaries and distillations of scholarly consensus on the significance of specific texts and themes in early Judaism.

In an epilogue, Henze explores the broader implications of Jesus' Jewishness ("What Difference Does It Make That Jesus Was a Jew?"), identifying three common "objections" he encounters in his public lectures. The first is that there is simply "too much Judaism" in his presentations (p. 183). Since Henze's focus on Jesus' Jewishness undercuts any assumption that Jesus was "Christian," Christian audiences sometimes feel like Henze is trying to take Jesus away from them. Henze counters this by pointing out that he wants to make people "increasingly aware of the Jewish world of Jesus" and "realize that Jesus was at home in the Judaism of 
first-century CE Israel” (p. 184). A second objection arises from the non-canonical status of the Intertestamental literature. Henze effectively counters this objection by pointing out that many more texts were produced by Jewish scribes than are contained in the Old or New Testaments and that it is important to be aware of this creative literary output. The third and most problematic response that Henze encounters is the theological objection that focusing on Jesus' Jewish context somehow undermines the uniqueness of Jesus and the Christian faith as divine revelation (pp. 186, 189). Henze suggests that this theological objection stems from an ancient but inappropriate use of comparison in order to "underscore the superiority of the New Testament" which, "in an extreme form," leads to replacementtheology or supersessionism (p. 190; emphasis in original).

Having responded to these common objections, Henze outlines three major challenges facing "Christian readers" today: (1) "to become familiar with the rich trove of Jewish texts"; (2) "to stay clear of the traps of supersessionism and of other ideologies that denigrate Judaism"; and (3) "to be mindful of the distinction between Jesus and his followers... and Christianity as an independent religion" (pp. 193-94). One can hardly object to any of these laudable goals. Henze's challenges could serve as a foundation for the Christian reader to engage in deep and meaningful discourse and reflection on the Christian tradition.

Yes, Jesus was Jewish, but "there is something unsettling about coming to realize that [Jesus]...was not a Christian but a Jew" (p. 2). There is, indeed. The Jewish Jesus does make (some) Christians uncomfortable. Why? Because remembering Jesus' Jewishness leads to asking questions like: Did "we" Christians get Jesus right? Why did (do) Jews "reject" Jesus? And why are "we" (Christians) not Jews, like Jesus? These questions can be historically and theologically destabilizing to people of faith. That is why they are either resisted, ignored, or, more commonly, answered with apologetic responses like "the Jews rejected Jesus" (because they were stiff-necked, blind, and / or hard-hearted) and / or Jesus "abolished" and / or "replaced" the (curse of the) Jewish law. That is also why it is essential that the rhetorical appeal to Jesus' Jewishness, while perhaps comforting within an inter-religious or inter-faith context, should continue to challenge and enlighten Jewish-Christian dialogue.

To be sure, a major theme of Mind the Gap is that "Jesus adhered to and practiced a specific form of Judaism" (p. 182; emphasis in original), that is, Second Temple Judaism. But given the great variety within Second Temple Judaism, we still need to ask what kind of Jew Jesus was within this complex cultural milieu. For most biblical scholars, this means reconstructing an "historical Jesus," that is, a hypothetical reconstruction of the life, teachings, beliefs, and activities of the Jesus of history. Henze insists, however, that this is not a "historical Jesus" book. Henze is "not concerned with the historical Jesus," but rather chooses to focus "on Jesus as we read about him in the four Gospels and in the letters of Paul" (p. 11). While this pronounced interest in the Jesus of the Gospels is understandable given Henze's literary focus and his presumed (Christian) audience, it does raise the issue of the relationship between the Jesus of the Gospels and the Jesus of history. The 
Jesus of the Gospels, after all, is a "Christian" Jesus - a Jesus shaped by the theological and ideological interests of an emergent, nascent "Christianity." And it is precisely within the pages of the New Testament that a dichotomous opposition between Jesus and Judaism was first inscribed as "gospel." To simply re-present the Jesus of the Gospels is to run the risk of re-inscribing that very same dichotomous opposition.

To be fair, Henze's goal here is simply to help general readers understand the Gospels' representation of (the Jewishness of) Jesus within Second Temple Judaism. Moreover, that audience is presumed to be Christian, as is evident in the book's subtitle about how "Jewish writings" help "us" understand Jesus. It would seem, then, that the modern (Christian) reader is in a bit of a quandary - willing to recognize that Jesus was Jewish, but not entirely sure how to reconcile the Jewish Jesus and the Christian Christ. We cannot expect Henze to solve this ancient dilemma. It is enough that he destabilizes assumptions, answers objections, and challenges facile theological dogmas even while he leaves Christians with the inherent tension and ambiguity of a Jewish Jesus. Biblical scholars will find much of this volume expertly articulated (albeit covering familiar territory), while many Christian readers will find Mind the Gap to be a courageous exploration of the social, political, and theological contexts of the New Testament. Insofar as the meaning(s) of texts are best understood in their original cultural contexts, Mind the Gap provides readers with the most assured results of contemporary scholarship on early Judaism. It also effectively counters unhelpful tendencies toward supersessionism within Christian theology by illustrating the close and even intimate relationships between Second Temple Jewish literature and early Christian texts. It is precisely this kind of methodological intervention, and its attendant discomfort, that holds the greatest potential for genuine Jewish-Christian dialogue. Accessible, readable, and personable, Mind the Gap is authoritative without being overly technical. It may well be the most useful introductory book for undergraduates, seminary students, and general readers trying to understand the literary, historical, and theological contexts of the New Testament writings about Jesus. 